\title{
SELECTED PERSONALITY TRAITS AND ACHIEVEMENT MOTIVATION IN UNIVERSI- TY STUDENTS OF PHYSICAL CULTURE, EDUCATION AND NATURAL SCIENCES
}

\author{
Martin Sigmund ${ }^{1}$, Jana Kvintováa ${ }^{2, *}$, Iva Dostálová ${ }^{1}$, Zdeněk Hamřík ${ }^{1}$
}

\author{
${ }^{1}$ Faculty of Physical Culture, Palacký University, Olomouc, Czech Republic \\ ${ }^{2}$ Faculty of Education, Palacký University, Olomouc, Czech Republic
}

Submitted in March, 2013

\begin{abstract}
BACKGROUND: Understanding personality variables and other important psychological traits in the university population appears topical particularly with respect to personality, motivation, health as well as overall academic achievement. A significant role is played by correlations of the monitored variables in relation to selected study specialization.

OBJECTIVE: The main objective of the present study is to extend the knowledge on selected personality traits and the level of achievement motivation in a specific group of university students with respect to the diversity of their study specialization.

METHODS: The study included a total of 522 students from Palacký University. These were students from the Faculty of Physical Culture $(n=118)$, Faculty of Education $(n=218)$ and Faculty of Science $(n=186)$. In terms of age, the study focused on young adults aged 19 to 26. In the research, psychodiagnostic methods were used to perform diagnostics and to fulfil the overall research plan. All diagnostic methods used are fully standardized and contain domestic normative values. We monitored variables such as personality, achievement motivation and achievement anxiety. Statistical result processing was conducted using the Statgraphics programme v. 9.0. Result processing was made using parametric as well as non-parametric statistical methods (Shapiro-Wilk, Mann-Whitney, Kruskal-Wallis, Spearman's correlation).

RESULTS: University students specialized in physical culture showed the highest values of extraversion and psychoticism, and clearly the lowest values of neuroticism compared to the students of education and natural sciences. The highest values of openness were observed in the students specialized in sports. In terms of the overall achievement motivation related to study specialization, almost identical values were observed. However, the students of physical culture showed significantly lower values of achievement debilitating anxiety than the students of education and natural sciences $(p \leq .001)$.

CONCLUSION: The present study deals with a psychological analysis of personality traits and achievement motivation in a sample of university students based on various study specializations. It appears that there are variances in personality traits among students of physical culture, education and natural sciences. On the contrary, in case of achievement motivation, the differences are negligible. The study falls within the category of differential diagnostics and the results can be applied in university psychological counselling.
\end{abstract}

Keywords: Psychology, academic diversity, adultus, sport.

\section{INTRODUCTION}

Understanding personality variables and other important psychological traits in the university population appears topical as the personality of a university student affects not only health but also academic achievement (Hamaideh, 2011). University students represent the

\footnotetext{
* Address for correspondence: Jana Kvintová, Department of Psychology and Psychopathology, Faculty of Education, Palacký University, Žižkovo nám. 5, 77140 Olomouc, Czech Republic. E-mail: jana.kvintova@upol.cz
}

national capital and future investment of every society. University students thus represent a specific population group. In terms of development, these are individuals whose age is characterized by reaching somatic, mental, emotional as well as social maturity (Provazníková, Štullerová, Provazník, \& Hynčica, 1999).

Preconditions for successful study are defined by the presence and mutual combination of abilities, selected personality traits, achievement and, last but not least, motivation. Several foreign studies point to a significant relationship between personality traits and motivation with respect to the process of study (Busato, Prins, Elshout, \& Hamaker; 2000; Clark \& Schroth, 
2010; Komarraju \& Karau, 2005; Komarraju, Karau, \& Schmeck, 2009; Ross, Rausch, \& Canada, 2003).

In this context, motivation is defined as one of the main determinants of academic achievement and success (Green, Nelson, Martin, \& Marsh, 2006; Linnenbrink \& Pintrich, 2002). Achievement motivation represents one of the most frequent terms used in sports psychology (Slepička, Hošek, \& Hátlová, 2006; Stackeová, 2010). In this context, achievement motivation is associated not only with sports achievement but generally with achievement as such.

Analysing the profile of a university student can largely contribute not only to the clarification of the relationship between personality traits and achievement motivation but also academic achievement and success. Linhartová (2008) presents general basic characteristics of contemporary university students, who are more open, critical or even overcritical, with strong self-confidence, using assertive behaviour, with good language skills and well-oriented in information technologies. In opposition to these personality traits is a lower degree of independence and responsibility.

The present study investigates selected psychological personality traits and achievement motivation in university students specialized in physical culture, education and natural sciences. The aim of the study is to extend the knowledge on selected personality traits and the level of achievement motivation in a specific group of university students with respect to the diversity of their study specialization. Motivation as such presents a significant personality component and therefore is monitored together with the selected personality traits. On the basis of the mentioned research study the principal research question is postulated as follows: "What is the basic psychological profile of selected personality traits and performance motivation in current university students with respect to gender differences and various study specializations?" The results of the study should enrich the database of current university population and be applicable in psychological counselling. The authors in their practise often work with the defined target group of individuals in the period of early adulthood. The present findings, in a specific practical context, help improve the quality of work with the client within psychological intervention and counselling.

\section{MATERIAL AND METHODS}

\section{Subjects}

The study involved a total of 522 students from three faculties of Palacký University. Specifically the students were from the Faculty of Physical Culture, Faculty of Education and Faculty of Science (Table 1). The survey and data collection was conducted according to a time plan in 2010 and 2011.
In the context of our research a present university student was any individual properly enrolled as a fulltime student whose age was adequate to the respective university grade. In terms of age, the study involved younger adults aged 19 to 26 . Most students were in the categories of 20, 21 and 22 years of age $\left(\sum n=420\right)$. With respect to age, these age categories represent in total more than $80 \%$ of the whole sample.

Table 1

Characteristics of study participants

\begin{tabular}{lcc}
\hline & $\begin{array}{c}\text { Number of } \\
\text { participants }\end{array}$ & Men/Women \\
\hline Faculty of Physical Culture & 118 & $50 / 68$ \\
Faculty of Education & 218 & $11 / 207$ \\
Faculty of Science & 186 & $70 / 116$ \\
TOTAL & 522 & $131 / 391$ \\
\hline
\end{tabular}

\section{Ethical aspects}

The study was conducted in compliance with ethical aspects. The survey involved adult individuals on a voluntary basis. Each participant was informed of a possibility to terminate participation at any stage without giving any reason. All data was processed anonymously, it was impossible to identify specific participants. The survey participants consented to anonymous data processing and use for scientific purposes.

\section{Psychological assessment}

In the study, we used psychodiagnostic methods that are fully standardized and include domestic normative values. To assess personality traits we used a five factor personality inventory (Big Five) - NEO (by P. T. Costa, R. R. McCraee), and the EPQ-R personality questionnaire (by H. J. Eysenck). Achievement motivation was assessed using an achievement motivation questionnaire (DMV) (Pardel, Maršálová, \& Hrabovská, 1984).

\section{Big Five Inventory}

The five factor personality inventory was originally designed by P. T. Costa a R. R. McCraee as NEO Five - Factor Inventory and adapted to Czech conditions by Hřebíčková and Urbánek (2001). This questionnaire is suitable for surveys aimed at individual personality differences. As the title suggests, it provides diagnostic data on five selected personality domains. These areas include the following:

- Neuroticism,

- Extraversion,

- Openness,

- Agreeableness,

- Conscientiousness. 


\section{EPQ-R personality questionnaire}

The EPQ-R questionnaire is ranked among the Eysenck personality questionnaires. Specifically, this is a shortened version of the reviewed EPQ personality questionnaire. The questionnaire was adapted to our conditions by Senka, Kováč, and Matejík (1993). The questionnaire is designed for measurement of basic personality dimensions, i.e. extraversion, neuroticism and psychoticism. In our research we primarily focussed on establishing the level of psychoticism, which is not taken into account by the five factor Big Five questionnaire.

Psychoticism is a rather controversial scale of this questionnaire. The term tends to be incorrectly associated with psychosis or psychiatric terms such as psychopathy, schizoid or behavioural disorders. The presented scale is designed for a common non-pathological population, therefore, the scale is pathological only in extreme cases in which the development of mental disorders is predetermined (only in a small proportion of individuals). For these reasons, in communication with common population, the authors recommended more socially acceptable terms such as tenacity or obstinacy. High values on the psychoticism scale tend to indicate individuals without interest in other people, with a lack of empathy and feelings for their surroundings as they can show aggressive and hostile behaviour towards relatives and friends. They are interested in extraordinary matters and might not consider possible risks.

The EPQ-R diagnostic questionnaire is not primarily designed for psychiatric diagnostics as it is used especially in the area of education and work-related psychology.

\section{Achievement motivation questionnaire (DMV)}

The achievement motivation questionnaire presents a modified version of the Herman's achievement motive test. The test was standardized and adapted to our conditions by Pardel, Maršálová, and Hrabovská (1984). The questionnaire covers three scales - achievement motive, achievement debilitating anxiety and achievement facilitating anxiety. Generally, these items relate to the following aspects - effort to reach good achievement, success, ambition and appreciation, and diligence, persistence and tenacity in dealing with difficult tasks.

As a diagnostic tool, this questionnaire can be used for the purposes of counselling, screening for problem individuals in terms of work and school achievement, and in other areas that require sound achievement and success in the respective activities.

\section{Statistical analysis}

Statistical result processing was conducted using the Statgraphics programme v. 9.0. For each variable, ba- sic statistical quantities were calculated and distribution normality verified. Result processing was made using parametric as well as non-parametric statistical methods. Normality was assessed using the ShapiroWilk normality test. To assess the differences and rate of significance between independent sets, the MannWhitney $U$ test was used. Multiple value comparison was made using the Kruskal-Wallis test and correlation dependences were assessed by Spearman's correlation. The level of statistical significance was tested at $p \leq .05$; $p \leq .01$.

The statistical significance is expressed in common $p$ values as well as in $d$ values, where $d$ is Cohen's coefficient for effect size defined as a difference between two means divided by a standard deviation for the data. The most frequent assessment of effect size $d$ is 0.2 - small effect, 0.5 - moderate and 0.8 - large effect (Cohen, 1988; Thomas, Nelson, \& Silverman, 2011).

\section{RESULTS}

The results present the observed values of selected personality traits and achievement motivation in university students of physical culture and students of education and natural sciences. The resulting data was compared with respect to gender differences and, particularly, in relation to selected study specializations. Table 2 shows the average values of the observed personality traits and achievement motivation.

Table 2

Selected personality traits and achievement motivation in university students $(N=522)$

\begin{tabular}{lcc}
\hline & $M \pm S D$ & Range \\
\hline Neuroticism & $23.1 \pm 4.89$ & $7-39$ \\
Psychoticism & $3.0 \pm 1.57$ & $0-10$ \\
Extraversion & $23.2 \pm 3.72$ & $14-38$ \\
Openness & $24.4 \pm 3.51$ & $12-35$ \\
Agreeableness & $26.3 \pm 4.17$ & $15-39$ \\
Conscientiousness & $27.6 \pm 3.68$ & $17-38$ \\
Achievement motive & $89.7 \pm 15.67$ & $40-134$ \\
Debilitating anxiety & $57.3 \pm 14.37$ & $19-102$ \\
Facilitating anxiety & $31.8 \pm 9.49$ & $10-57$ \\
\hline
\end{tabular}

Table 3 presents the values of correlation coefficients (Spearman) of selected personality traits, achievement motivation and anxiety relating to the achievement in the whole sample of university students. Significant values are observed at $p \leq .05$. Of the monitored parameters, the most significant positive correlation was observed between neuroticism and debilitating anxiety. It was also confirmed that a higher rate of psychoticism is strongly related to a generally 
lower level of achievement motivation. Psychoticism is negatively linked with the level of debilitating anxiety. Extraversion is significantly associated with overall level of achievement motivation and at the same time with the level of achievement facilitating anxiety. Openness shows a significant link with the level of facilitating anxiety. Agreeableness is positively related to overall achievement motivation and debilitating anxiety. Significant correlations were further observed in the values of conscientiousness, particularly with respect to overall achievement motivation. A significant positive correlation was also identified between conscientiousness and debilitating anxiety (Table 3 ).

Table 3

Spearman's correlation of selected personality traits and achievement motivation

\begin{tabular}{lccc}
\hline & AM & DA & FA \\
\hline Neuroticism & .02 & $.53^{*}$ & -.01 \\
Psychoticism & $-.20^{*}$ & $-.26^{*}$ & .00 \\
Extraversion & $.20^{*}$ & .01 & $.19^{*}$ \\
Openness & .05 & .05 & $.15^{*}$ \\
Agreeableness & $.20^{*}$ & $.17^{*}$ & .06 \\
Conscientiousness & $.45^{*}$ & $.21^{*}$ & .00 \\
\hline
\end{tabular}

Note. $\quad \mathrm{AM}=$ achievement motive, $\mathrm{DA}=$ debilitating (inhibiting) anxiety, FA = facilitating (supporting) anxiety $* p \leq .05$.

Gender comparison of selected personality traits in university students shows significantly higher neuroticism values in women $(p \leq .001)$. On the contrary, significantly higher psychoticism values were observed in men $(p \leq .001)$. In other personality traits, no significant gender-based differences were observed (Table 3).
The overall values of achievement motivation were significantly higher in women $(p \leq .003)$. Women also show significantly higher values of debilitating anxiety $(p \leq .001)$. Conversely, men show significantly higher values of achievement facilitating anxiety $(p \leq .019)$ (Table 4).

The comparison of study specializations reveals interesting results. University students specialized in physical culture show clearly the lowest values of neuroticism compared to the students of education and natural sciences $(p \leq .009 ; p \leq .001)$. The highest psychoticism values were observed in students of physical culture and natural sciences; these values were significantly higher in comparison to the students of education. The students of physical culture show higher extraversion values than other students; in comparison to the students of education the difference is significant $(p \leq .044)$. Also in openness, the students of physical culture show the highest values. In personality traits such as agreeableness and conscientiousness, no significant differences were observed with respect to the study specialization (Table 5).

The overall level of achievement motivation in the monitored samples is almost identical. Minimum differences with respect to study specialization were observed. At the same time, clearly the lowest values of debilitating anxiety were observed in the students of physical culture in comparison to the students of education ( $p \leq .001 ; d=0.49)$ and the students of natural sciences $(p \leq .001 ; d=0.54)$. The values of facilitating anxiety do not show any significant differences in terms of study specialization (Table 6).

Table 4

Selected personality traits and achievement motivation in university students

\begin{tabular}{|c|c|c|c|c|c|c|}
\hline & \multicolumn{2}{|c|}{ Men, $n=131$} & \multicolumn{2}{|c|}{ Women, $n=391$} & \multirow[b]{2}{*}{$p$} & \multirow{2}{*}{$\begin{array}{c}\text { Cohen's } \\
d\end{array}$} \\
\hline & $M \pm S D$ & Range & $M \pm S D$ & Range & & \\
\hline Neuroticism & $22.6 \pm 4.89$ & $7-33$ & $23.3 \pm 4.89$ & $8-39$ & $.001 * * *$ & 0.14 \\
\hline Psychoticism & $3.7 \pm 1.86$ & $0-8$ & $2.7 \pm 1.36$ & $0-10$ & $.001 * * *$ & 0.67 \\
\hline Extraversion & $27.4 \pm 3.54$ & $14-36$ & $27.2 \pm 3.78$ & $16-38$ & .542 & 0.05 \\
\hline Openness & $24.7 \pm 3.72$ & $16-35$ & $24.3 \pm 3.43$ & $12-32$ & .237 & 0.11 \\
\hline Agreeableness & $26.7 \pm 4.71$ & $16-37$ & $26.1 \pm 3.97$ & $15-39$ & .532 & 0.14 \\
\hline Conscientiousness & $27.2 \pm 4.17$ & $18-37$ & $27.7 \pm 3.50$ & $17-38$ & .211 & 0.14 \\
\hline Achievement motive & $86.2 \pm 17.02$ & $40-134$ & $90.9 \pm 15.02$ & $47-130$ & $.003 * *$ & 0.30 \\
\hline Debilitating anxiety & $51.2 \pm 15.73$ & $19-102$ & $59.4 \pm 13.27$ & $23-97$ & $<.001 * * *$ & 0.59 \\
\hline Facilitating anxiety & $33.4 \pm 10.01$ & $10-57$ & $31.2 \pm 9.28$ & $10-57$ & $.019 *$ & 0.23 \\
\hline
\end{tabular}

Note. $* p \leq .05, * * p \leq .01,{ }^{* * *} p \leq .001$. 
Table 5

Selected personality traits in university students of physical culture, education and natural sciences

\begin{tabular}{|c|c|c|c|c|c|c|}
\hline & $M \pm S D$ & Range & $H$ & Comp. & $p$ & Cohen's $d$ \\
\hline \multicolumn{7}{|c|}{ Neuroticism } \\
\hline $\mathrm{P}$ & $21.4 \pm 5.01$ & $19-26$ & \multirow{3}{*}{$\begin{array}{l}16.60 \\
p<.001\end{array}$} & P-E & $.009 * *$ & 0.40 \\
\hline $\mathrm{E}$ & $23.3 \pm 4.61$ & $20-25$ & & $\mathrm{P}-\mathrm{N}$ & $<.001^{* * *}$ & 0.50 \\
\hline $\mathrm{N}$ & $23.9 \pm 4.93$ & $8-38$ & & $\mathrm{E}-\mathrm{N}$ & NS & 0.13 \\
\hline \multicolumn{7}{|c|}{ Psychoticism } \\
\hline$P$ & $3.4 \pm 1.56$ & $0-8$ & \multirow{3}{*}{$\begin{array}{l}31.03 \\
p<.001\end{array}$} & P-E & $<.001 * * *$ & 0.63 \\
\hline $\mathrm{E}$ & $2.5 \pm 1.37$ & $0-10$ & & $\mathrm{P}-\mathrm{N}$ & NS & 0.12 \\
\hline $\mathrm{N}$ & $3.2 \pm 1.66$ & $0-9$ & & $\mathrm{E}-\mathrm{N}$ & $.001 * * *$ & 0.46 \\
\hline \multicolumn{7}{|c|}{ Extraversion } \\
\hline $\mathrm{P}$ & $28.1 \pm 3.12$ & $22-38$ & \multirow{3}{*}{$\begin{array}{l}5.99 \\
p=.050\end{array}$} & P-E & $.044^{*}$ & 0.34 \\
\hline $\mathrm{E}$ & $26.9 \pm 3.71$ & $17-36$ & & $\mathrm{P}-\mathrm{N}$ & NS & 0.24 \\
\hline $\mathrm{S}$ & $27.2 \pm 4.00$ & $14-36$ & & $\mathrm{E}-\mathrm{N}$ & NS & 0.08 \\
\hline \multicolumn{7}{|c|}{ Openness } \\
\hline$P$ & $25.2 \pm 3.35$ & $18-33$ & \multirow{3}{*}{$\begin{array}{l}9.34 \\
p=.009\end{array}$} & P-E & $.009 * *$ & 0.40 \\
\hline E & $23.8 \pm 3.52$ & $12-32$ & & $\mathrm{P}-\mathrm{N}$ & NS & 0.26 \\
\hline $\mathrm{S}$ & $24.6 \pm 3.50$ & $17-35$ & & $\mathrm{E}-\mathrm{N}$ & NS & 0.23 \\
\hline \multicolumn{7}{|c|}{ Agreeableness } \\
\hline $\mathrm{P}$ & $26.0 \pm 4.19$ & $17-37$ & \multirow{3}{*}{$\begin{array}{l}1.04 \\
p=.595\end{array}$} & P-E & NS & 0.01 \\
\hline $\mathrm{E}$ & $26.4 \pm 4.13$ & $15-39$ & & $\mathrm{P}-\mathrm{N}$ & NS & 0.05 \\
\hline $\mathrm{S}$ & $26.2 \pm 4.21$ & $16-36$ & & $\mathrm{E}-\mathrm{N}$ & NS & 0.05 \\
\hline \multicolumn{7}{|c|}{ Conscientiousness } \\
\hline $\mathrm{P}$ & $27.8 \pm 3.57$ & $18-35$ & \multirow{3}{*}{$\begin{array}{l}1.55 \\
p=.460\end{array}$} & P-E & NS & 0.06 \\
\hline $\mathrm{E}$ & $27.6 \pm 3.39$ & $17-36$ & & $\mathrm{P}-\mathrm{N}$ & NS & 0.10 \\
\hline S & $27.4 \pm 4.07$ & $18-38$ & & $\mathrm{E}-\mathrm{N}$ & NS & 0.05 \\
\hline
\end{tabular}

Note. $\quad H=$ Kruskal-Wallis test score, Comp. = comparison. $\mathrm{P}=$ Faculty of Physical Culture, $\mathrm{E}=$ Faculty of Education, $\mathrm{S}=$ Faculty of Science. NS $=$ not significant, ${ }^{*} p \leq .05,{ }^{* *} p \leq .01,{ }^{* * *} p \leq .001$.

Table 6

Achievement motivation in university students of physical culture, education and natural sciences

\begin{tabular}{|c|c|c|c|c|c|c|}
\hline & $M \pm S D$ & Range & $H$ & Comp. & $p$ & Cohen's $d$ \\
\hline \multicolumn{7}{|c|}{ Achievement motive } \\
\hline $\mathrm{P}$ & $89.6 \pm 16.39$ & $40-134$ & \multirow{3}{*}{$\begin{array}{l}0.05 \\
p=.979\end{array}$} & P-E & NS & 0.00 \\
\hline E & $89.6 \pm 14.11$ & $47-130$ & & $\mathrm{P}-\mathrm{N}$ & NS & 0.02 \\
\hline S & $89.9 \pm 16.98$ & $47-134$ & & $\mathrm{E}-\mathrm{N}$ & NS & 0.02 \\
\hline \multicolumn{7}{|c|}{ Debilitating anxiety } \\
\hline $\mathrm{P}$ & $51.7 \pm 14.75$ & 19-97 & \multirow{3}{*}{$\begin{array}{l}22.79 \\
p<.001\end{array}$} & P-E & $<.001 * * *$ & 0.49 \\
\hline $\mathrm{E}$ & $58.4 \pm 13.06$ & $21-102$ & & $\mathrm{P}-\mathrm{N}$ & $<.001 * * *$ & 0.54 \\
\hline S & $59.7 \pm 14.73$ & $20-95$ & & $\mathrm{E}-\mathrm{N}$ & NS & 0.09 \\
\hline \multicolumn{7}{|c|}{ Facilitating anxiety } \\
\hline $\mathrm{P}$ & $32.0 \pm 9.35$ & $10-57$ & \multirow{3}{*}{$\begin{array}{l}1.02 \\
p=.599\end{array}$} & P-E & NS & 0.06 \\
\hline $\mathrm{E}$ & $31.4 \pm 9.37$ & $10-57$ & & $\mathrm{P}-\mathrm{N}$ & NS & 0.01 \\
\hline S & $32.1 \pm 9.74$ & $10-53$ & & $\mathrm{E}-\mathrm{N}$ & NS & 0.07 \\
\hline
\end{tabular}

Note. $\quad H=$ Kruskal-Wallis test score, Comp. = comparison. $\mathrm{P}=$ Faculty of Physical Culture, $\mathrm{E}=$ Faculty of Education, $\mathrm{S}=$ Faculty of Science. NS $=$ not significant, ${ }^{* * *} \mathrm{p} \leq .001$. 


\section{DISCUSSION}

The results of the present study should enrich the databank in information about selected psychological aspects in the monitored population and at the same time should facilitate the transfer into practical context. University psychological counselling and work with individuals in early adulthood typically brings various issues and situations. One of the most topical issues is mental health. University students show a relatively high degree of affinity for stressors. It is anticipated that the high degree of stress influences not only students' health but also their academic achievement. It appears that the most frequent group of stressors include selfimposed stressors followed by exogenous pressures. The most frequent responses to stressors include cognitive answers (Hamaideh, 2011). Generally, university students are typical for a significantly higher degree of harmful stress compared with the common population (Stallman, 2008; Walsh, Feeney, Hussey, \& Donnellan, 2010). An important preventive factor reducing individual stress seems to be the selection of students for a specific type of study. It can be anticipated that a suitable and targeted form of selection reduces possible stress during university study (Kožený, Höschl, \& Tišanská, 2002). The issue of increased mental load and the stress factor are considered the most hazardous environmental factors affecting the susceptibility to depression and other mental problems (Margitics \& Pauwlik, 2008). The experienced distress is often positively correlated with using destructive coping strategies (Chen, Lin, Wang, \& Hou, 2009). University students face a significantly higher number of multiple stressors compared with their non-student peers. A similar example could be found in young employees in health care and beginning physicians, whose level of stress is significantly higher compared with the common population of the same age (Buddeberg-Fischer, Stamm, Buddeberg, \& Klaghofer, 2009). A sufficient amount of scientific information is required particularly to maintain good health of the current university students. This information can then be practically used to effectively work with an individual or a group in psychological and counselling interventions.

The selected personality traits of extraversion, neuroticism and psychoticism in the whole sample of university students $(N=522)$ did not show significant deviations from normative values. University students specialized in sports showed the highest values of extraversion. University students specialized in sports showed considerably lower values of neuroticism compared to students of education or natural sciences $(p \leq .009 ; p \leq .001)$. University students specialized in sports showed the highest values of psychoticism. The highest values of openness were observed in the students specialized in sports. In terms of the overall achievement motivation related to study specialization, almost identical values were observed. However, the students of physical culture showed significantly lower values of achievement debilitating anxiety than the students of education and natural sciences $(p \leq .001)$.

The frequently discussed prerequisites for the successful coping with university study include a combination of factors of personality, abilities and required motivation. In the context of this study, we focus on assessment of selected personality traits of achievement motivation in university students of physical culture in comparison to students of education and natural sciences.

Ahadi and Narimani (2010) point to correlations between personality traits, stress and study achievement in university students. In terms of personality observed in university students, a significant positive correlation between conscientiousness, extraversion and openness to experience, agreeableness and academic achievement was identified. It was also confirmed that various stress situations including study stress significantly decrease academic achievement. On the contrary, academic achievement is supported by extraversion and conscientiousness.

In terms of the monitored personality variables in the research sample it was observed that university students who specialized in sports show the highest extraversion values. According to Ahadi and Narimani (2010), the increased extraversion values can be considered a predictor of academic achievement. It is also apparent that extraversion has a positive effect on the reduction of academic stress (Aghajanipour \& Homayouni, 2010). It should also be stated that a higher extraversion level represents a significant predictor of addictive substance use by university students (Orosová \& Gajdošová, 2009). Therefore, both poles of these personality traits must be considered in order to promote a strategy for the development of personal competences leading to a balanced academic regime.

The differences in extraversion are considerably higher in the students specialized in sports compared to the students of education and natural sciences. The students specialized in sports divide their time between theoretical and practical study. They often include active athletes, mostly specialized in team sports, therefore, a higher rate of extraversion is observed. This personality trait is a significant factor allowing athletes effective cooperation in the dynamics of a sports team. A certain grade of extraversion is also required for individual sports because athletes need to be involved with other fellow and team members. Therefore, we believe that a considerably higher rate of extraversion observed in university students who specialized in sports is predisposed by a combination of their personality and sports environment, in which the personality is shaped 
during the different stages of ontogenetic development. In practice, this is often a period from younger school age, sometimes earlier. Bunevicius, Katkute, and $\mathrm{Bu}-$ nevicius (2008) refer to some differences between students of medicine and humanities. It was observed that students of humanities are significantly more open to experience and more extraverted compared to students of medicine.

In terms of another psychological variable - neuroticism - the highest rate was observed in university students of natural sciences, followed by the students of education. The observed values are significantly higher than neuroticism values in the students specialized in sports. To a certain extent, these results correspond with the findings by Plháková and Reiterová (2010). In their study of university students specialized in humanities and natural sciences it was revealed that university students of humanities (psychology) were less neurotic and more open to experience compared to students of natural sciences (mathematics and informatics). Plháková and Reiterová point to a fact that psychology students reach significantly better results in social and emotional skills compared to students of mathematics and informatics.

In terms of gender differences, clearly the highest neuroticism values were observed in our sample of women. A significantly higher level of neuroticism in women of this age category is also stated by Petrová (1995). Similarly, Kohoutek (1998) in a study of the personality of university students indicates higher neuroticism values in women compared to men. A higher incidence of $\mathrm{N}$-score in women is confirmed by Miglierini and Vonkomer (1979) in their earlier study.

It is neuroticism that is often defined as one of the fundamental personality traits largely influencing academic achievement, motivation and coping (Hamaideh, 2011). Vollrath and Torgersen (2000) point to a fact that university students with a high neuroticism values and a low conscientiousness level show high vulnerability to stress and effective stress coping. A group of students with low neuroticism and high conscientiousness had the most favourable stress profile and effective coping. The effect of neuroticism itself was not clear. The effect, however, was obvious in combination with conscientiousness. Neuroticism is significantly correlated with university stress and has a significant influence on the development of somatic symptoms ( $\mathrm{Lu}$, 1994). Students with a high neuroticism score also show lower achievement motivation needs and a high degree of elusion (Komarraju \& Karau, 2005).

Another personality variable is psychoticism. In our sample, psychoticism is significantly higher in male university students. In this case psychoticism is not approached in the context of psychopathology; instead, the scale is designed for common non-pathological population. Only in extreme cases possible develop- ment of mental abnormalities can be indicated. In our survey the term denotes certain personality tenacity or obstinacy. In terms of study specialization, the highest psychoticism values were observed in the students of physical culture, slightly lower in the students of natural sciences. Clearly the lowest values were recorded by the students of natural sciences. This result could have been influenced by a certain degree of disparateness of the different subsamples in terms of a higher representation of women in the students of natural sciences. It can thus be assumed that this imbalance had an effect on the observed lower value of psychoticism. Generally, however, the level of psychoticism in our university students is significantly negatively correlated with the overall level of achievement motivation.

Another monitored personality trait was openness with the highest values observed in the students of physical culture. Compared to the students of education the difference is significant. To a certain extent, the results correspond with the level of extraversion, which was also prominent in the students of physical culture. Clark and Schroth (2010) confirmed the role of openness as one of the main personality factors predicting academic motivation. Lounsbury, Welsh, and Gibson (2005) also highlight this fact. Our survey indicated a significantly positive correlation between openness and a component of achievement motivation - achievement facilitating anxiety.

In the personality trait of conscientiousness, minimum differences were identified between the students of physical culture and other samples. However, this personality factor is often and repeatedly associated with academic achievement as a significant predictor (Higgins, Peterson, Lee, \& Pihl, 2007; Noftle \& Robins, 2007). This fact is supported by our findings indicating a significant correlation between conscientiousness and achievement motivation in a sample of university students. Komarraju and Karau (2005) refer to significant associations between personality and motivation, particularly between conscientiousness and motivation to succeed.

In terms of motivation Komarraju, Karau, and Schmeck (2009) point to a positive correlation between intrinsic motivation and conscientiousness with coincident openness to new experience. It was also observed that university students with a higher degree of extrinsic motivation are more extraverted with an increased level of neuroticism. Students with the lowest degree of motivation appear to be unpleasant with insufficient conscientiousness. Wagerman and Funder (2007) consider the factor of conscientiousness a valid and unique predictor of study results. Previous research also confirmed the role of openness to experience as one of the main personality factors predicting academic motivation (Clark \& Schroth, 2010). Blatný (2001) cor- 
relates an increased level of extraversion not only with the level of self-assessment and life satisfaction but also with overall emotional stability and conscientiousness. Provided that there is a significant correlation between extraversion and conscientiousness, we can assume that our results confirm similar conclusions of positive correlations between extraversion, conscientiousness and achievement motivation. In this context, conscientiousness can be understood as a saturating source of the motivation process.

Another focus of the study was the relationship between university students and motivation. Average values of achievement motivation in the different samples revealed that there is almost no difference in achievement motivation values in relation to selected specializations. Average achievement motivation values are almost identical in all three samples. It can thus be concluded that the level of achievement motivation is not correlated with selected study specializations as no differences were observed among university students of education, natural sciences and sports.

In our research hypothesis we postulated a significantly higher achievement motivation in students of sports. The hypothesis was also based on McClelland's (Atkinsonová, Atkinson, Smith, Bem, \& Nolen-Hoeksema, 2003; Nakonečný, 1992; Robbins \& Decenzo, 2001) statement that achievement motivation can also be of an autotelic nature. This means that an individual is not motivated to achievement only by satisfying their own needs but also by achievement itself. We expected this fact to have an effect on achievement motivation of university students specialized in sports in relation to other study specializations. We believed that students of physical culture, being active athletes, would show their needs for achievement developed from an early age in achievement motivation values. Hošek (1986) states that in the development of an achievement motivation structure during the childhood stage is crucial. According to the methods of education applied, the child develops prevailing tendencies to reach success or avoid failure. The decisive aspect of child education is strengthening chances of success or fear of failure. This also applies to adult individuals (Bedrnová \& Nový, 2002). The development of a need for success depends primarily on the parents' achievement orientation and personal experience with success (Atkinsonová et al., 2003; Hošek, 1986; Muchinsky, 2000; Robbins \& Decenzo, 2001; Štikař, Rymeš, Riegel, \& Hoskovec, 2003).

The assumption of higher achievement motivation in our sample of students of physical culture was not confirmed and it can be concluded that motivation processes and achievement are to a certain extent affected by anxiety; both debilitating and facilitating.
In terms of debilitating anxiety it was observed that university students who specialized in sports report clearly the lowest values compared to students of education and natural sciences ( $p \leq .001 ; d=0.49 ; d=0.54$ ). Regarding the fact that no significant differences were observed in the level of achievement motivation, the course of activities aimed at achievement delivery can be affected by debilitating anxiety. If this component of the achievement motivation structure is considerably lower in university students specialized in sports, they can theoretically reach better results because they are significantly less influenced by negative anxiety.

One of the strengths of the present study is that the presented findings are based on a relatively large number of specific participants of current university population of various study specializations. The presented findings enrich the database of scientific information on specific individuals specializing in different fields of study. With respect to practical applicability of the findings, an important factor is the transfer to the area of university psychological counselling. This is a separate psychological area, where the results of this type of survey can be used to their full potential.

A certain limitation of the present study is the absence of the randomization principle. For this reason, the results of the survey cannot be fully generalized to the wide population of current university students. Also, a higher proportion of women, particularly students of education, can have an influence on the resulting values.

Regarding the mentioned strengths and possible limitations of the study, the results provide valuable information based on which causal hypotheses can be formulated and then verified in research and practice.

\section{CONCLUSIONS}

The present study deals with selected personality traits and achievement motivation in contemporary university students specialized in physical culture, education and natural sciences.

In terms of the present results we can make the following comments on the results of our research and facts that can be regarded typical in our sample of university students:

- university students specialized in sports show significantly lower values of neuroticism,

- university students specialized in sports show the highest values of psychoticism of all monitored samples,

- university students specialized in sports show the highest values of extraversion,

- university students specialized in sports show the highest values of openness to new experience, 
- personal characteristic of "extraversion" is significantly positively correlated with the level of performance motivation,

- personal characteristic of "neuroticism" is not correlated with the level of performance motivation,

- personal characteristic of "psychoticism" is significantly negatively correlated with the level of performance motivation,

- the level of performance motivation is not correlated with study (professional) specialization,

- the level of performance debilitating anxiety is significantly lower in university students who specialize in sports.

- in other personality traits such as agreeableness and conscientiousness, no significant differences in study specializations were observed.

Overall values of achievement motivation show minimum differences with respect to study specializations. Clearly the lowest values of debilitating anxiety were observed in the students of physical culture compared to the students of education and natural sciences. The values of facilitating anxiety do not show significant differences in terms of study specializations.

Obtaining information about the student population presents a significant factor of potential development of various forms of assistance such as promotion programmes aimed at coping with stress situations. Better understanding of personality profiles of university students can be helpful in academic and career selection and can play a role in the prevention of possible mental issues. Therefore, the health of university students is recently becoming an area of increased interest because it is university students who present the national capital and future investment.

\section{ACKNOWLEDGMENTS}

This work was supported by the the ECOP project "Strengthening the scientific potential of research teams in promoting physical activity at Palacky University“, reg. no. CZ.1.07/2.3.00/20.0171 (90\%) and the Slovak Research and Development Agency under contract no. APVV-0032-11 (10\%).

\section{REFERENCES}

Aghajanipour, H., \& Homayouni, A. (2010). Personality factors related to emerge of stress in university students. European Psychiatry, 25(1), 875.

Ahadi, B., \& Narimani, M. (2010). Study of realtionships between personality traits and education. Trakia Journal of Sciences, 8(3), 53-60.
Atkinson, R. L., Atkinson, R. C., Smith, E. E., Bem, D. J., \& Nolen-Hoeksema, S. (2003). Psychologie (2nd rev. ed.). Praha: Victoria Publishing.

Bedrnová, E., \& Nový, I. (2002). Psychologie a sociologie rízení. Praha: Management Press.

Blatný, M. (2001). Osobnostní determinanty sebehodnocení a životní spokojenosti: Mezipohlavní rozdíly. Československá psychologie, 45(6), 385-392.

Buddeberg-Fischer, B., Stamm, M., Buddeberg, C., \& Klaghofer, R. (2010). Chronic stress experience in young physicians: Impact of person and workplace-related factors. International Archives of Occupational and Environmental Health, 83(4), 373-379.

Bunevicius, A., Katkute, A., \& Bunevicius, R. (2008). Symptoms of anxiety and depression in medical students and in humanities students: Relationship with big-five personality dimensions and vulnerability to stress. International Journal of Social Psychiatry, 54(6), 494-501.

Busato, V. V., Prins, F. J., Elshout, J. J., \& Hamaker, C. (2000). Intellectual ability, learning style, personality, achievement motivation and academic success of psychology students in higher education. Personality and Individual Differences, 29, 1057-1068.

Chen, C. K., Lin, C., Wang, S. H., \& Hou, T. H. (2009). A study of job stress, stress coping strategies, and job satisfaction for nurses working in middle-level hospital operating rooms. Journal of Nursing Research, 17, 199-211.

Cohen, J. (1988). Statistical power analysis for the behavioral sciences (4th ed.). New York, NY: Academic Press.

Clark, M. H., \& Schroth, C. A. (2010). Examining relationships between academic motivation and personality among college students. Learning and individual differences, 20, 19-24.

Green, J., Nelson, J., Martin, A. J., \& Marsh H. W. (2006). The causal ordering of self-concept and academic motivation and its effect on academic achievement. International Education Journal, 7(4), 534-546.

Hamaideh, S. H. (2011). Stressors and reactions to stressors among university students. International Journal of Social Psychiatry, 57(1), 69-80.

Higgins, D. M., Peterson, J. B., Lee, A. G. M., \& Pihl, R. O. (2007). Prefrontal cognitive ability, intelligence, Big Five personality, and the prediction of advanced academic and workplace performance. Journal of Personality and Social Psychology, 93, 298-319.

Hošek, V. (1986). Motivace sportovního tréninku. Praha: Univerzita Karlova.

Hřebičková, M., \& Urbánek, T. (2001). NEO-pětifaktorový osobnostní inventár. Praha: Testcentrum. 
Kohoutek, R. (1998). Osobnost a sebepoznání studentů. Brno: Akademické nakladatelství CERM.

Komarraju, M., \& Karau, S. J. (2005). The relationship between the big five personality traits and academic motivation. Personality and Individual Differences, 39, 557-567.

Komarraju, M., Karau, S. J., \& Schmeck, R. R. (2009). Role of the big five personality traits in predicting college students' academic motivation and achievement. Learning and Individual Differences, 19(1), 47-52.

Kožený, J., Höschl, C., \& Tišanská, L. (2002). Akademický výkon a úspěch v 1 . a 2. ročníku integrovaného studia medicíny na 3. LF UK: Prediktivní potenciál přijímacího řízení [Academic performance and achievement in the 1 st and 2 nd year of integrated study of medicine at the 3rd LF UK: The predictive potential of the admission process]. Československá psychologie, 46(3), 208-218.

Linhartová, D. (2008). Vysokoškolská psychologie [College psychology]. Brno: MZLU.

Linnenbrink, E. A., \& Pintrich, P. R. (2002). Motivation as an enabler for academic success. School Psychology Review, 31, 313-327.

Lu, L. (1994). University transition: Major and minor life stressors, personality characteristics and mental health. Psychological Medicine, 24(1), 81-87.

Margitics, F., \& Pauwlik, Z. (2008). Gender differences in proneness to depression. Psychiatria Hungarica, 23(6), 444-454.

Muchinsky, P. M. (2000). Psychology applied to work. Belmont: Wadsworth.

Nakonečný, M. (1992). Motivace pracovního jednání a její rízení [Motivation of work negotiation and its management]. Praha: Management Press.

Orosová, O., \& Gajdošová, B. (2009). Individuálne a sociálne faktory fajčenia cigariet a konzumácie alkoholu u vybraných skupín vysokoškolských študentov [Individual and social factors, cigarette smoking and alcohol consumption in selected groups of university students]. Československá psychologie, 53(6), 600-611.

Pardel, T., Maršálová, L., \& Hrabovská, A. (1984). Dotazník motivácie výkonu - príručka [Questionnaire of performance motivation - guide]. Bratislava: Psychodiagnostické a didaktické testy.

Petrová, A. (1995). Sebeobraz a sebepojetí ve strukture osobnosti adolescentù. Disertační práce, Univerzita Palackého, Filozofická fakulta, Olomouc.

Plháková, A., \& Reiterová, E. (2010). Rozdíly v pěti dimenzích osobnosti a sociální inteligenci mezi studenty exaktních a humanitních věd. Československá psychologie, 54(2), 147-159.

Provazníková, H., Štullerová, N., Provazník, K., \& Hynčica, V. (1999). Vliv studijních a životních podmí- nek na zdravotní stav a studijní úspěchy vysokoškoláků. Psychológia a patopsychológia dietata, 25(6), 501-511.

Robbins, S. P., \& Decenzo, D. A. (2001). Fundamentals of management. Upper Saddle River, NJ: Prentice Hall.

Ross, S. R., Rausch, M. K., \& Canada, K. E. (2003). Competition and cooperation in the five factor model: Individual differences in achievement orientation. The Journal of Psychology, 137(4), 323-337.

Senka, J., Kováč, T., \& Matejík, M. (1992). Eysenckove osobnostné dotazníky pre dospelých - príručka [Eysenck's personality inventories for adults - guide]. Bratislava: Psychodiagnostika.

Slepička, P., Hošek, V., \& Hátlová, B. (2006). Psychologie sportu [Sport psychology]. Praha: Karolinum.

Stackeová, D. (2010). Perspektivy tématu výkonové motivace $\mathrm{v}$ kinantropologii [Perspectives of performance motivation in kinanthropology]. Česká kinatropologie, 14(1), 9-18.

Stallman, H. M. (2008). Prevalence of psychological distress in university students - implications for service delivery. Australian Family Physician, 37(8), 673-677.

Štikař, J., Rymeš, M., Riegel, K., \& Hoskovec, J. (2003). Psychologie ve světě práce [Psychology in the world of work]. Praha: Univerzita Karlova.

Thomas, J. R., Nelson, J. K., \& Silverman, S. J. (2011). Research methods in physical activity (6th ed.). Champaign, IL: Human Kinetics.

Vollrath, M., \& Torgersen, S. (2000). Personality types and coping. Personality and Individual Differences, 29(2), 367-378.

Walsh, J. M., Feeney, C., Hussey, J., \& Donnellan, C. (2010). Sources of stress and psychological morbidity among undergraduate physiotherapy students. Physiotherapy, 96(3), 206-212.

\section{VYBRANÉ OSOBNOSTNÍ CHARAKTERISTIKY A VÝKONOVÁ MOTIVACE U VYSOKOŠKOL- SKÝCH STUDENTŮ TĚLESNÉ KULTURY, PEDAGOGIKY A PŘíRODNÍCH VĚD}

(Souhrn anglickeho textu)

VÝCHODISKA: Poznání osobnostních proměnných a dalších důležitých psychologických charakteristik u vysokoškolské populace se jeví jako aktuální téma, právě s ohledem na osobnost, motivaci, zdraví i celkový akademický výkon. Důležitou roli pak sehrávají vzájemné vztahy sledovaných proměnných s ohledem ke zvolené studijní specializaci.

CíLE: Hlavním cílem předložené práce je rozšíření poznatků o vybraných osobnostních charakteristikách a úrovni výkonové motivace u specifické skupiny sou- 
časných vysokoškolských studentů ve vztahu k rozdílnému studijnímu zaměření.

METODIKA: Výzkumu se zúčastnilo celkem 522 studentů Univerzity Palackého v Olomouci. Jednalo se o studenty z Fakulty tělesné kultury $(n=118)$, z Pedagogické fakulty $(n=218)$ a Př́rodovědecké fakulty $(n=186)$. Z hlediska věku se jedná o jedince v období mladší dospělosti ve věkovém rozpětí mezi 19-26 let. V rámci vlastního výzkumného šetření byly použity celkem tři psychodiagnostické metody, které jsou plně standardizované a obsahují domácí normativní hodnoty. Sledovány byly proměnné, jako je osobnost, motivace $\mathrm{k}$ výkonu a anxieta. Konkrétně byly použity následující psychodiagnostické metody: NEO - pětifaktorový osobnostní inventář tzv. Big Five, osobnostní dotazník EPQ-R a Dotazník motivace výkonu (DMV). Statistické zpracování výsledků bylo provedeno pomocí programu Statgraphics vers. 9.0. a kvantitativních statistických metod.

VÝSLEDKY: Vybrané osobnostní charakteristiky extraverze, neuroticismus a psychoticismus u celého souboru vysokoškolských studentů $(N=522)$ nevykazují významné diference od normativních hodnot. Vysokoškolští studenti se zaměřením na tělesnou kulturu vykazují signifikantně nejnižší hodnoty neuroticismu ve vztahu ke studentům pedagogické a přírodovědecké fakulty. Nejvyšši hodnoty psychoticismu byly zjištěny u studentů tělesné kultury a studentů př́rodovědecké fakulty, a to signifikantní ve vztahu ke studentům z fakulty pedagogické. Studenti tělesné kultury vykazují nejvyšší hodnoty extraverze ve srovnání se studenty dalších specializací. Rovněž v otevřenosti zkušenostem vykazují studenti tělesné kultury nejvyšší hodnoty ve srovnání s dalšími soubory. V osobnostních charakteristikách, jako je př́větivost a svědomitost, nebyly zjištěny signifikantní diference s ohledem na studijní zaměření. Obdobně nebyly zjištěny diference v hodnotách výkonové motivace s ohledem na zvolenou studijní specializaci.

ZÁVĚRY: Předložená studie se zabývá psychologickou analýzou osobnostních charakteristik a výkonové motivace u souboru vysokoškolských studentů s ohledem na různé studijní zaměření. Předložené výsledky poukazují na určité diference v osobnostních rysech a komponentách výkonové motivace u studentů tělesné kultury v porovnání se soubory studentů pedagogického, resp. prrírodovědeckého zaměření. Není tomu tak v úrovni výkonové motivace. Výsledky šetření nacházejí své praktické uplatnění v oblasti vysokoškolského psychologického poradenství při práci s definovanou cílovou skupinou.

Klíčová slova: psychologie, studijní zaměrení, mladši dospělost, tělesná kultura. 